\title{
URGENSI PENGATURAN PERTANGGUNGJAWABAN PIDANA KORPORASI DALAM KEJAHATAN TERHADAP SATWA LIAR
}

\author{
Fajar Winarni* \\ Departemen Hukum Lingkungan, Fakultas Hukum, Universitas Gadjah Mada \\ Jalan Sosio Yustisia No. 1, Bulaksumur Sleman, Yogyakarta 55281.
}

\begin{abstract}
Wildlife crimes committed by corporations cannot be charged with Act No. 5 of 1990 concerning The Conservation of Biodiversity and Its Ecosystem, because this Act does not regulate it. This research is a normative study by examining crimes that are formulated in laws whose mode is reasonably suspected of involving corporations. Crimes committed by corporations will have a major impact on the balance of the ecosystem, so it is very important to accommodate corporate criminal liability in a special law on conservation. The regulation of corporate criminal liability includes who is called a corporation, who can be sentenced to crime, what types of sanctions are appropriate for the corporation so that it will have a deterrent effect
\end{abstract}

Keywords: Corporate Criminal Liability, Wildlife Crime

\section{Intisari}

Kejahatan satwa liar yang dilakukan oleh korporasi tidak dapat dijerat dengan Undang-Undang No. 5 Tahun 1990 tentang Konservasi Keanekaragaman Hayati dan Ekosistemnya (UUKH), karena UUKH tidak mengaturnya. Penelitian ini merupakan penelitian normative dengan mengkaji kejahatan yang dirumuskan dalam undang-undang yang modusnya patut diduga melibatkan korporasi. Kejahatan yang dilakukan korporasi akan menimbulkan dampak yang besar terhadap keseimbangan ekosistem, sehingga sangatlah penting untuk mengakomodasi pertanggungjawaban pidana korporasi dalam sebuah undangundang khusus mengenai konservasi. Pengaturan pertanggungjawaban pidana korporasi meliputi siapa yang disebut sebagai korporasi, siapa saja yang dapat dijatuhi pidana, jenis sanksi apa yang tepat untuk korporasi sehingga akan menimbulkan efek jera.

Kata kunci: Pertanggungjawaban pidana korporasi, kejahatan satwa liar

\section{Pokok Muatan}

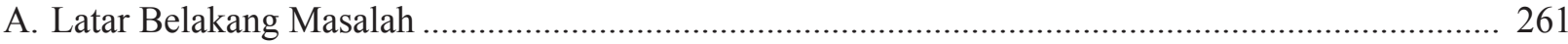

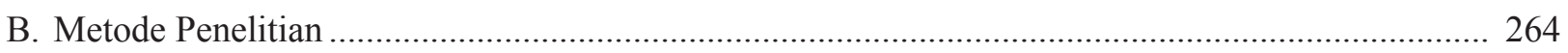

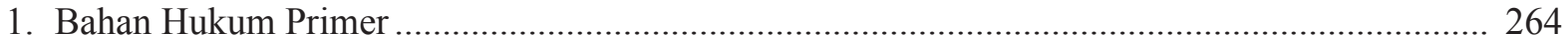

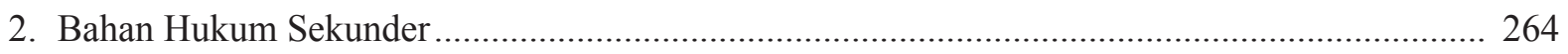

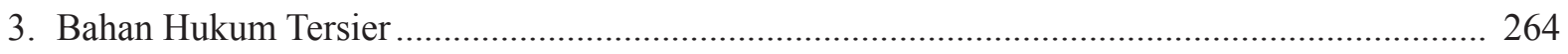

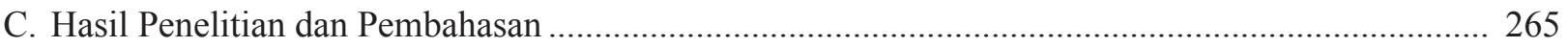

1. Urgensi Pengaturan Pertanggungjawaban Pidana Korporasi Dalam Kejahatan Satwa Liar....... 265

2. Pengaturan Pertanggungjawaban Pidana Korporasi Dikaitkan Dengan Kejahatan Terhadap

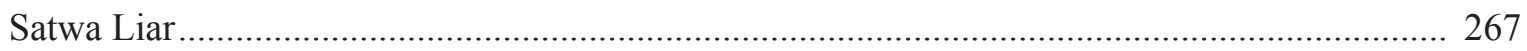

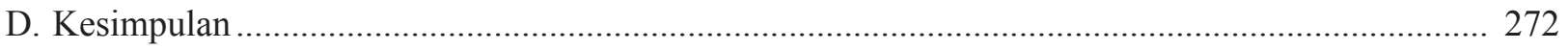

Alamat Korespondensi: fajar.winarni@mail.ugm.ac.id. 


\section{A. Latar Belakang Masalah}

Sumber daya alam hayati Indonesia yang terdiri atas sumber daya alam hewani, sumber daya alam nabati, serta ekosistemnya merupakan karunia Tuhan yang Maha Esa yang dapat dijadikan sebagai salah satu modal dasar pembangunan nasional yang berkelanjutan. Indonesia merupakan salah satu dari tiga negara dengan keanekaragaman hayati tertinggi di dunia, sehingga disebut sebagai negara megabiodiversity. Indonesia juga memiliki tingkat endemik keanekaragaman hayati yang tinggi, dari 38.000 spesies tumbuhan, 55\% nya merupakan spesies endemik, sedangkan dari 512 spesies binatang menyusui, 39\% nya merupakan spesies endemik. ${ }^{1}$

Berdasarkan kondisi saat ini, spesies-spesies tersebut banyak yang terancam punah. Rusaknya hutan menyebabkan satwa liar kehilangan sumber makanan, habitat tempat tinggal, dan ruang jelajah untuk berkembang biak. Satwa liar yang habitatnya terganggu menjelajah perkebunan atau kawasan tempat tinggal manusia, sehingga terjadi konflik antara satwa liar dan manusia yang berakhir dengan kematian satwa karena ditangkap paksa atau diracun. Perdagangan, perburuan, dan penangkapan satwa liar secara berlebihan juga menjadi pemicu kepunahan spesies tersebut. Perubahan iklim, polusi, dan invasif spesies berdampak pada habitat dan ekosistem serta kemampuan spesies bertahan hidup dan berkembang biak. ${ }^{2}$

Penyebab utama dari beberapa penyebab berkurangnya dan punahnya spesies adalah aktivitas manusia yang tidak berkelanjutan atau tidak ramah lingkungan. Keberlanjutan kelestarian satwa liar Indonesia sangat bergantung pada komitmen semua stakeholders, terutama pemerintah sebagai pembuat kebijakan. Konservasi keanekaragaman hayati dan ekosistemnya merupakan tanggung jawab pemerintah beserta masyarakat. Konservasi tersebut dilakukan melalui kegiatan perlindungan sistem penyangga kehidupan, pengawetan keanekaragaman jenis tumbuhan dan satwa beserta ekosistemnya, dan pemanfaatan secara lestari sumber daya alam hayati dan ekosistemnya.

Tahun 2015 sampai dengan tahun 2018, upaya penegakan hukum keanekaragaman hayati menurut data Wildlife Crime Unit Wildlife Conservation Society Indonesian Program, jumlah kasus kejahatan satwa liar dilindungi tercatat meningkat tajam dari 106 kasus pada tahun 2015 menjadi 225 kasus pada tahun 2017. Peningkatan kasus ini dapat diartikan sebagai nasib baik dan dapat pula diartikan sebagai nasib buruk. Baik karena penegak hukum makin giat dan serius menindak kejahatan satwa liar, sehingga makin banyak kasus yang terungkap, dan buruk karena ternyata dari tahun ke tahun upaya pencegahan tidak berhasil. Satwa liar Indonesia terus berada dalam ancaman. Pada bulan Oktober 2018 tercatat penurunan kasus menjadi 169 kasus, yang relatif masih tinggi. ${ }^{3}$

Ada hal menarik dari berbagai kasus kejahatan terhadap satwa liar, yaitu penggunaan korporasi sebagai wadah perbuatan kejahatan tersebut. Namun jika dilihat dalam Undang-Undang Nomor 5 Tahun 1990 tentang Konservasi Sumber Daya Alam Hayati dan Ekosistemnya (selanjutnya disebut UUKH), undang-undang ini belum mengatur atau mengakomodasi pertanggungjawaban pidana korporasi. Akibatnya korporasi yang terlibat dalam kejahatan terhadap satwa liar tidak dapat tersentuh oleh hukum. Sementara itu, meskipun telah ada upaya untuk merevisi UUKH, namun pada tanggal 4 April 2018 Pemerintah secara resmi menghentikan proses revisi undang-undang tersebut.

Contoh kasus kejahatan terhadap satwa liar yang menggunakan korporasi adalah kasus penyelundupan sirip hiu yang dilakukan oleh Perusahaan CV SS pada tahun 2016. Dari hasil

Raynaldo Sembiring dan Wenni Adzkia, "Memberantas Kejahatan atas Satwa Liar: Refleksi Atas Penegakan Hukum UU No. 5 Tahun 1990”, Jurnal Hukum Lingkungan, Vol. 2, Issue 2, 2015.

WWF, “Spesies", https://www.wwf.or.id,diakses Tanggal 8 Maret 2019.

Kelompok Kerja Konservasi, 2018, Catatan Akhir tahun 2018 Kelompok Kerja Konservasi: nasib gantung Konservasi Keanekaragaman Hayati, Kerjasama ICEL, FKKM, KEHATI, PILI, WWF, WCS , hlm. 3. 
pemeriksaan petugas Kantor Pengawasan dan Pelayanan Bea dan Cukai Tipe Madya Pabean Tanjung Perak menemukan sirip hiu yang dikemas dalam 352 kantong yang tersimpan dalam kontainer berukuran 40 kaki. Menurut rencana, sirip hiu itu akan dikirim ke Hong Kong. Modus yang digunakan pelaku untuk menyelundupkan hiu adalah dengan memalsukan informasi dokumen ekspor barang, yang diberitahukan sebagai perut ikan beku. Sirip hiu tersebut diperkirakan berasal dari jenis hiu martil dan hiu biru dengan berat total 20.184 kilogram $(\mathrm{kg})$. Hiu martil merupakan salah satu dari 73 jenis ikan hiu yang dilindungi. Dua di antara 73 jenis itu habitatnya berada di Indonesia, yaitu hiu martil dan hiu koboi. CV SS diduga melakukan pelanggaran Undang-Undang Nomor 16 Tahun 1992 tentang Karantina Hewan, Ikan, dan Tumbuhan (yang saat ini sudah diganti dengan Undang-Undang Nomor 21 Tahun 2019 tentang Karantina, Hewan, Ikan, dan Tumbuhan), dan Undang-Undang Nomor 31 Tahun 2004 tentang Perikanan sebagaimana telah diubah dengan Undang-Undang Nomor 45 Tahun 2009. Kasus ini telah dilimpahkan ke Balai Karantina Ikan, Pengendalian mutu dan Keamanan hasil Perikanan kelas I Surabaya.

Selain itu, ada pula upaya penyelundupan ubur-ubur (jelly fish) yang dilakukan oleh CV SIS. Modus yang digunakan yaitu memberikan informasi tidak benar dalam dokumen pemberitahuan ekspor barang. Dalam dokumen tersebut CV SIS memberikan informasi akan melakukan ekspor salted jelly fish sebanyak 4.040 buckets atau 88.880 $\mathrm{kg}$. Namun dalam pemeriksaan petugas menemukan lebih banyak ubur-ubur yaitu 4.246 buckets atau setara dengan $93.412 \mathrm{~kg}$. Selain pemberitahuan tidak benar, ekspor tersebut juga tidak dilengkapi dengan sertifikat kesehatan. ${ }^{4}$ Selain itu, ada kasus lembaga konservasi yang dijadikan modus dalam kepemilikan satwa illegal, yaitu kasus P.T.
Nuansa Alam Nusantara di Padang Lawas Utara, Sumatra Utara. Dalam kasus tersebut Markas Besar Kepolisian Negara Republik Indonesia (selanjutnya disebut Mabes Polri) mengamankan dan menyita berbagai satwa dilindungi di Mini Zoo P.T. Nuansa Alam Nusantara. Puluhan satwa terancam punah yang dimiliki oleh PT tersebut diduga illegal karena izin yang dimiliki masih merupakan izin sementara. Contoh lain, lembaga penangkaran seringkali digunakan sebagai alat untuk pencucian satwa dengan mengklaim satwa liar dilindungi sebagai hasil penangkaran, sebagaimana yang terjadi dalam kasus CV Bintang Terang di Jawa Timur. ${ }^{5}$

Berdasarkan kasus-kasus tersebut, jika dilihat dari pelaku utamanya yaitu korporasi, maka mereka tidak dapat dijerat dengan UUKH, karena dalam UUKH tidak mengatur pertanggungjawaban pidana korporasi. Pemerintah mendorong penggunaan undang-undang terkait tindak pidana pencucian uang untuk menjerat pelaku kejahatan satwa.

Undang-Undang Nomor 8 Tahun 2010 tentang Pencegahan dan Pemberantasan Tindak Pidana Pencucian Uang (selanjutnya disebut UU TPPU) dapat digunakan untuk memburu kekuatan keuangan dibalik kejahatan yang dilakukan, sekaligus menelusuri pelaku-pelakunya di lapangan sampai otak pelaku dan pemilik modal, mengingat motif utama dari terjadinya kejahatan ini adalah kepentingan ekonomi. ${ }^{6}$ Selain itu dalam UU TPPU sanksi pidananya lebih berat dibandingkan dengan UUKH. Namun demikian fokus sasaran dari UU TPPU berbeda dengan UUKH. UU TPPU lebih menyasar pada kepentingan ekonomi, karena kejahatan terhadap satwa liar dinilai akan merugikan perekonomian global. Sementara UUKH merupakan UU yang salah satu sasaran pengaturannya adalah perlindungan satwa liar. Dengan demikian sangatlah relevan apabila UUKH mengatur secara spesifik pertanggungjawaban pidana korporasi terkait

Kementerian Keuangan, "20 Ton Sirip Hiu Gagal ke Hong Kong”, https://www.kemenkeu.go.id//publikasi/berita/20-ton-sirip-hiu-gagal-kehong-kong/, diakses 17 Maret 2019

Policy Brief 6, Proyeksi Penerapan Pertanggungjawaban Korporasi dalam Kejahatan Konservasi, ICEL, Jakarta, 2019, hlm. 4.

Nur Arinta, "PPATK: Mari Bersama Stop Perdagangan Ilegal Satwa Liar Dilindungi Hingga ke Akarnya", wwf.id/publikasi/ppatk-maribersama-stop-perdagangan-ilegal-satwa-liar-dilindungi-hingga-ke-akarnya, diakses Tanggal 6 September 2020. 
dengan kejahatan satwa liar, karena kejahatan ini tidak hanya merugikan keuangan negara, tetapi juga merugikan kepentingan konservasi lingkungan hidup, seperti penurunan keanekaragaman hayati yang akan berdampak pada ketersediaan pangan, risiko kerusakan seluruh ekosistem, dan kesehatan manusia.

Melihat kecenderungan hukum yang ada, pertanggungjawaban pidana korporasi semakin banyak diakomodasi dalam berbagai peraturan perundang-undangan, hal ini menunjukkan kesadaran pembentuk undang-undang akan dampak besar kejahatan yang dilakukan oleh korporasi. ${ }^{7}$

Secara teoretis, hukum pidana pada awalnya membatasi subjek hukum yang dapat dikenai pidana sebatas pada natural person atau individu. Begitu juga dalam Kitab Undang-Undang Hukum Pidana (KUHP) yang menganut pandangan bahwa badan hukum tidak dapat dipidana, karena tidak memiliki kesadaran dan tidak punya badan aktual. Dengan meningkatnya peran badan hukum dalam kegiatan perekonomian dan mulai diterimanya doktrin functional daderschap (pelaku fungsional), korporasi atau badan hukum mulai diposisikan sebagai pihak yang dapat dimintakan pertanggungjawaban. ${ }^{8}$

Kejahatan satwa liar merupakan salah satu kategori kejahatan lintas batas yang terorganisir. Kejahatan lintas batas atau lintas negara merupakan bentuk kejahatan yang menjadi ancaman serius terhadap keamanan dan kemakmuran global, mengingat sifatnya yang melibatkan berbagai negara. Untuk menanggulangi kejahatan tersebut, diciptakan sebuah mekanisme multilateral melalui sebuah perjanjian internasional yaitu United Nations Convention on Transnational Organized Crime (selanjutnya disebut UNTOC) yang dibentuk pada tahun 2000. Tahun 2010 Conference of State Parties (selanjutnya disebut CoSP) UNTOC yang ke lima telah mengidentifikasi beberapa kejahatan lintas negara baru dan berkembang (New and Emerging Crimes), antara lain cybercrime, identityrelated crimes, perdagangan gelap benda cagar budaya, kejahatan lingkungan, pembajakan di atas laut, dan perdagangan gelap organ tubuh. Indonesia mempunyai kepentingan besar agar kejahatan lintas negara baru dapat diatur secara lebih komprehensif karena kerugian besar yang ditimbulkan dari kejahatan tersebut, termasuk dengan cara kerjasama dalam rangka peningkatan kapasitas penegak hukum dan pertukaran informasi. ${ }^{9}$

Untuk mencegah atau meminimalisasi kejahatan terhadap satwa liar di Indonesia, yang merupakan salah satu kejahatan terorganisir, harus dimulai dari tingkat nasional. Pada umumnya akar permasalahan adalah pada aspek normatif atau peraturannya. Kekosongan hukum pertanggungjawaban pidana korporasi dalam pemberantasan kejahatan terhadap satwa liar, mengakibatkan dampak yang masif bagi keberlanjutan keanekaragaman hayati Indonesia, terutama keberadaan satwa liar tersebut. Dampak yang paling parah adalah punahnya satwa-satwa tersebut, yang tentu sangat diperlukan bagi keseimbangan ekosistem.

Menteri Lingkungan Hidup dan Kehutanan, Siti Nurbaya, menyebut kasus kejahatan satwa liar menjadi salah satu yang terbesar terjadi di Indonesia. Kasus ini berada di bawah kasus kejahatan narkotika dan obat-obatan terlarang serta perdagangan manusia. Di Indonesia kejahatan satwa liar menduduki peringkat ke-3 setelah kejahatan narkoba dan perdagangan manusia. Demi penguatan upaya pemberantasan kejahatan satwa liar, Kementerian Lingkungan Hidup dan Kehutanan memperkuat sistem surveillance dan intelijen berbasiskan teknologi informasi, di antaranya pemantauan perdagangan satwa ilegal

Policy Brief, Op.cit., hlm. 5.

Raynaldo Sembiring, et al., 2014, Anotasi Undang-Undang Nomor 32 Tahun 2009 Tentang Perlindungan dan Pengelolaan LIngkungan Hidup Edisi I, ICEL, Jakarta, hlm. 265-266.

Kementerian Luar Negeri RI, "Kejahatan Lintas Negara", https://www.kemlu.go.id, diakses 10 Maret 2019. 
secara online melalui Cyber Patrol, membangun sistem Pemantauan Kerawanan Keamanan Hutan (Spartan) terpadu, dan terintegrasi dengan Center of Intelligen Penegakan Hukum Lingkungan Hidup dan Kehutanan. ${ }^{10}$

Berdasarkan latar belakang tersebut, dalam penelitian ini dirumuskan dua permasalahan, yaitu pertama, mengapa pertanggungjawaban pidana korporasi dalam kejahatan satwa liar perlu diatur? kedua, bagaimanakah pengaturan pertanggungjawaban korporasi dikaitkan dengan kejahatan satwa liar?

\section{B. Metode Penelitian}

Penelitian ini merupakan penelitian hukum normatif, yaitu penelitian hukum yang meletakkan hukum sebagai sebuah bangunan sistem norma. Sistem norma yang dimaksud adalah mengenai asas-asas, norma, kaidah dari peraturan perundangundangan, putusan pengadilan, perjanjian, serta doktrin (ajaran). ${ }^{11}$ Penelitian ini dilakukan dengan cara mengkaji kejahatan yang dirumuskan dalam undang-undang yang modusnya patut diduga melibatkan korporasi. Aturan hukum ini dapat berupa asas hukum, peraturan perundang-undangan yang saat ini berlaku (hukum positif) di bidang pertanggungjawaban pidana korporasi dalam masalah lingkungan hidup khususnya kejahatan terhadap satwa liar.

Bahan penelitian dalam penelitian ini adalah data sekunder. Bahan penelitian didapat dengan penelitian kepustakaan. Untuk itu, penelitian dilakukan dengan studi pustaka yang mengkaji bahan hukum. Data yang didapat dari penelitian kepustakaan adalah data sekunder. Data sekunder meliputi: ${ }^{12}$

\section{Bahan Hukum Primer}

Bahan hukum primer yaitu bahan hukum yang bersifat mengikat, yaitu peraturan hukum da- lam bidang hukum lingkungan yang terkait dengan masalah pertanggungjawaban pidana korporasi dalam kejahatan terhadap satwa liar, meliputi: UU No. 32 Tahun 2009 tentang Perlindungan dan Pengelolaan Lingkungan Hidup, KUHP, UU No. 5 Tahun 1990 tentang Konservasi Sumber Daya Alam Hayati dan Ekosistemnya, PP No. 7 Tahun 1999 tentang Pengawetan Jenis Tumbuhan dan Satwa, UU No. 8 Tahun 2010 tentang Pencegahan dan Pemberantasan Tindak Pidana Pencucian Uang, UU No. 17 Tahun 2006 tentang Perubahan Atas UU No. 10 Tahun 1995 tentang Kepabeanan, UU No. 41 Tahun 1999 tentang Kehutanan, UU No. 21 Tahun 2019 tentang Karantina Hewan, Ikan dan Tumbuhan.

\section{Bahan Hukum Sekunder}

Bahan hukum sekunder yaitu bahan hukum yang memberikan penjelasan mengenai bahan hukum primer, meliputi buku-buku mengenai kejahatan satwa liar dan pertanggungjawaban pidana korporasi, jurnal, hasil seminar, makalah, dan artikel yang ada kaitannya dengan tema penelitian, serta artikel dari internet.

\section{Bahan Hukum Tersier}

Bahan hukum tersier yaitu bahan yang memberikan petunjuk atau penjelasan terhadap bahan hukum primer dan sekunder, meliputi kamus hukum, kamus bahasa Inggris.

Teknik pengumpulan data dalam penelitian ini dilakukan dengan studi pustaka terhadap bahan-bahan hukum, baik bahan hukum primer, bahan hukum sekunder, maupun bahan hukum tersier. Penelusuran bahan-bahan hukum tersebut dilakukan dengan membaca dan penelusuran lewat media internet.

Metode analisis data yang digunakan adalah deskriptif kualitatif, yaitu dengan menjelaskan data sekunder yang diperoleh dari penelitian

10 Tsarina Maharani, "Menteri Lingkungan Hidup dan Kehutanan: Kejahatan satwa Liar Peringkat ke-3 di Indonesia", https://m. detik.com., diakses 10 Maret 2019

Mukti Fajar dan Yulianto Achmad, 2010, Dualisme Penelitian Hukum Normatif dan Empiris, Cetakan I, Pustaka Pelajar, Yogyakarta, hlm. 34 Soerjono Soekanto, 1986, Pengantar Penelitian Hukum, UI Press, Jakarta, hlm. 51-52 
kepustakaan untuk mendapatkan suatu kesimpulan sebagai jawaban dari permasalahan yang dirumuskan.

\section{Hasil Penelitian dan Pembahasan}

1. Urgensi Pengaturan Pertanggungjawaban Pidana Korporasi Dalam Kejahatan Satwa Liar

Convention of International Trade on Endangered Species (CITES) mendefinisikan wildlife sebagai seluruh satwa dan tumbuhan, sedangkan kejahatan didefinisikan sebagai suatu tindakan yang bertentangan dengan hukum nasional dan ketentuan mengenai perlindungan dan pengelolaan sumber daya alam termasuk ketentuan CITES. Sementara itu definisi satwa liar menurut Pasal 1 angka 7 UUKH adalah semua binatang yang hidup di darat, dan/atau di air, dan/atau di udara yang masih mempunyai sifat-sifat liar, baik yang hidup bebas maupun yang dipelihara oleh manusia. Adapun definisi khusus tentang kejahatan satwa liar, tidak ada dalam UUKH maupun peraturan pelaksanaannya. Kejahatan satwa liar dapat disimpulkan dari ketentuan Pasal 21 ayat (2) UUKH. Raynaldo Sembiring memberikan batasan definisi kejahatan atas kehidupan liar sebagai suatu tindakan terhadap satwa dan tumbuhan yang bertentangan dengan peraturan perundangundangan nasional dan ketentuan lainnya terkait perlindungan dan pengelolaan satwa dan tumbuhan, termasuk ketentuan CITES. Kejahatan atas satwa liar dapat berupa kejahatan atas satwa liar yang dilindungi, kejahatan atas satwa tidak dilindungi yang berada di kawasan yang dilindungi, termasuk pelanggaran terhadap ketentuan CITES. ${ }^{13}$

Salah satu prinsip pembangunan berkelanjutan adalah perlindungan keanekaragaman hayati (conservation of biological diversity). Prinsip ini merupakan target utama pembangunan berkelanjutan karena sumber daya ekologis memberikan manusia makanan dan obat-obatan, produk industri, menjaga kesuburan tanah, dan memberikan air bersih. Keanekaragaman hayati juga berfungsi sebagai tempat dan sumber rekreasi bagi umat manusia, sumber inspirasi, dan identitas budaya suatu bangsa. Oleh karena itu perlindungan keanekaragaman hayati merupakan sumber kesejahteraan bagi manusia. Upaya perlindungan keanekaragaman hayati tidak hanya menyangkut permasalahan moral dan etika tetapi juga hidup matinya manusia. ${ }^{14}$

Terkait dengan perlindungan keanekaragaman hayati khususnya satwa liar, UUKH memberikan perlindungan melalui pengawetan keanekaragaman jenisnya dan pemanfaatan jenis tumbuhan dan satwa liar. Pengawetan keanekaragaman tumbuhan dan satwa serta ekosistemnya dilakukan dengan menjaga keutuhan kawasan suaka alam agar tetap dalam keadaan asli. Pengawetan jenis tumbuhan dan satwa dilaksanakan di dalam dan di luar kawasan suaka alam. Pengawetan yang dilakukan di dalam suaka alam dilaksanakan dengan membiarkan agar populasi semua jenis tumbuhan dan satwa tetap seimbang menurut proses alami di habitatnya. Sementara itu pengawetan yang dilakukan dilakukan di luar suaka alam dilaksanakan dengan menjaga dan mengembangkanbiakkan jenis tumbuhan dan satwa untuk menghindari bahaya kepunahan.

Satwa liar merupakan sumber daya alam yang dapat diperbarui, dan Indonesia termasuk negara tropis yang memiliki keragaman yang tinggi. Sesuai dengan prinsip-prinsip strategi konservasi dunia, maka program pengelolaan satwa liar di Indonesia juga mencakup aspek perlindungan, pelestarian, dan pemanfaatan. Adapun tujuan pengelolaan satwa liar adalah sebagai berikut: ${ }^{15}$ a) Untuk meningkatkan ukuran populasi, terutama bagi jenisjenis yang kondisi populasi dan penyebarannya semakin tertekan; b) Untuk memanen sejumlah individu dari suatu populasi berdasarkan prinsip

\footnotetext{
Raynaldo Sembiring dan Wenni Adzkia, Op. cit., hlm. 51.

Mas Achmad Santosa, 2016, Alam pun Butuh Hukum dan Keadilan, Cetakan I, Prima Pustaka, Jakarta, hlm. 7.

Hadi S. Alikodra, 2012, Konservasi Sumber Daya Alam dan Lingkungan: Pendekatan Ecosophy bagi Penyelamatan Bumi, Cetakan I, Gadjah Mada University Press, Yogyakarta, hlm. 271 dan 276.
} 
kelestarian hasil, sehingga individu-individu yang tertinggal mempunyai potensi untuk mencapai produktivitas yang maksimum, misalnya pada pengelolaan taman buru atau penangkaran satwa liar; c) Untuk mengurangi individu yang jumlahnya berlebihan misalnya pada pengelolaan satwa liar di taman nasional atau di suaka marga satwa. Cara ini dikenal sebagai culling.

Kerusakan dan perubahan habitat akibat kegiatan dan populasi manusia yang semakin meningkat, dengan segala aspeknya merupakan faktor utama pemacu berbagai bentuk kepunahan satwa alami atau menurunnya keanekaragaman sumber daya hayati satwa alami. Jenis-jenis kegiatan tersebut di antaranya kegiatan eksploitasi pertambangan, kegiatan Hak Pengusahaan Hutan $(\mathrm{HPH})$, permukiman transmigrasi, perkembangan industri, perkembangan pertanian, perkebunan, peternakan, perikanan, dan kegiatan lainnya. ${ }^{16}$

Berdasar perkembangan awal hukum lingkungan di berbagai Negara, sanksi yang dikenakan bagi korporasi pada masa itu biasanya berupa denda, yang jumlahnya sangat tidak signifikan dibandingkan dengan kerusakan yang ditimbulkan dan ongkos ekonomi yang dibutuhkan untuk memulihkan lingkungan hidup. Sanksi ini tidak memberikan efek jera bagi pelaku usaha atau kegiatan. Atas dasar inilah berbagai negara mulai mengatur perilaku korporasi melalui pemidanaan yang memberikan sanksi denda dalam jumlah yang sangat besar maupun kemungkinan untuk memenjarakan personel korporasi. ${ }^{17}$ Dalam pengaturan pertanggungjawaban pidana korporasi, ancaman pidananya lebih berat dibandingkan apabila kejahatan itu dilakukan oleh perorangan. Sebagian besar peraturan perundang-undangan menetapkan sanksi pidananya diperberat sepertiga dari sanksi pidana jika kejahatan dilakukan oleh perorangan, misalnya dalam Undang-Undang Nomor 32 Tahun 2009 tentang Perlindungan dan Pengelolaaan Lingkungan Hidup, UndangnUndang Nomor 31 Tahun 2004 jo Undang-Undang Nomor 45 Tahun 2009 tentang Perikanan, dan sebagainya, yang Penulis bahas dalam sub bab Pengaturan Pertanggungjawaban Pidana Korporasi Dikaitkan Dengan Kejahatan Terhadap Satwa Liar.

Sebagaimana diketahui maraknya kejahatan terhadap satwa liar dikarenakan kegiatan tersebut bernilai ekonomis tinggi, di samping tingkat kesadaran masyarakat terhadap pentingnya peran satwa di dalam ekosistem masih relatif rendah. Di sisi lain peluang korporasi untuk melakukan kejahatan itu sangat besar, namun ancaman pidana yang diberikan oleh UUKH tidak sebanding dengan kerugian terhadap lingkungan hidup dari kejahatan ini.

Kejahatan korporasi di bidang lingkungan hidup timbul dari tujuan dan kepentingan korporasi yang bersifat menyimpang sehubungan dengan peranannya dalam pemanfaatan dan pengelolaan sumber daya alam, kegitan-kegiatan perindustrian dengan memanfaatkan ilmu pengetahuan dan teknologi maju untuk mencapai sasaran pembangunan di bidang ekonomi. Tanpa mempedulikan eksistensi makhluk hidup lainnya, baik manusia, hewan, maupun tumbuhan, serta memandang dan menempatkan lingkungan hidup sebagai objek yang berkonotasi komoditi dan dapat dieksploitasi untuk tujuan dan kepentingan organisasional berupa prioritization of profit. Perilaku menyimpang oleh korporasi itu telah membawa dampak bencana bagi lingkungan hidup dan kemanusiaan. ${ }^{18}$

Perbedaan kejahatan yang dilakukan oleh korporasi apabila dibandingkan dengan kejahatan yang dilakukan oleh perorangan, yaitu bahwa kejahatan yang dilakukan korporasi umumnya dilakukan secara sitematis dan menimbulkan dampak yang besar terhadap lingkungan hidup.

\footnotetext{
Jatna Supriatna, 2008, Melestarikan Alam Indonesia, Edisi pertama, Yayasan Obor Indonesia, Yogyakarta, hlm. 121. Raynaldo Sembiring, Op. cit., hlm. 266.

Muhammad Topan, 2009, Kejahatan Korporasi di Bidang Lingkungan Hidup: Perspektif Viktimologi Dalam Pembaharuan Hukum Pidana di
} Indonesia, Cetakan I, Nusa Media, Bandung, hlm.52. 
Tipologi keterlibatan korporasi dalam kejahatan konservasi adalah sebagai berikut: ${ }^{19}$

\section{a. Pemilikan dan Perdagangan Satwa Illegal}

Beberapa kasus pemilikan dan perdagangan satwa ilegal melibatkan korporasi, baik korporasi yang berbentuk badan hukum maupun non-badan hukum.

Badan usaha yang terlibat biasanya adalah Lembaga konservasi dan Lembaga penangkaran. Lembaga konservasi dapat dijadikan modus dalam kepemilikan satwa ilegal, seperti kasus kebun binatang ilegal, PT Nuansa Alam Nusantara Lembaga, di Padang Lawas. Sementara itu, lembaga penangkaran seringkali digunakan sebagai alat untuk pencucian satwa (wildlife laundering) dengan mengklaim satwa liar dilindungi sebagai hasil penangkaran, sebagaimana yang terjadi pada kasus CV Bintang Terang di Jawa Timur.

\section{b. Perusakan Kawasan Konservasi}

Kegiatan perkebunan, pertambangan dan kehutanan kadang kala tumpang tindih dengan kawasan hutan, dan kawasan hutan ini di beberapa kasus merupakan kawasan konservasi. Seperti dalam kasus perkebunan kelapa sawit di dalam Taman Nasional Tesso Nilo. Kasus lain adalah perusakan terumbu karang di kawasan konservasi laut Raja Ampat oleh kapal Caledonian Sky.

\section{c. Aktivitas di Kawasan Non- Konservasi yang Berdampak pada Spesies Dilindungi.}

Status dilindungi pada spesies tertentu tetap melekat meskipun ia berada diluar kawasan konservasi. Hal ini berarti kewajiban melindungi dan larangan terkait spesies dilindungi tetap ada bagi setiap usaha meskipun usaha tersebut berada diluar kawasan konservasi. Beberapa aktivitas korporasi diluar kawasan konservasi meng- akibatkan kerusakan pada spesies dilindungi, seperti pembunuhan orangutan di kawasan perkebunan, dan kebakaran lahan yang berdampak pada spesies dilindungi.

Dari ketiga tipologi tersebut, yang relevan dengan penelitian Penulis adalah tipe UUKH hanya mengatur tindak pidana yang dilakukan oleh perorangan. Dengan demikian ada kekosongan hukum dalam UUKH terkait pertanggungjawaban pidana korporasi. Oleh karena itu untuk menjaga keberlanjutan keanekaragaman hayati Indonesia, pengaturan pertanggungjawaban pidana korporasi terkait kejahatan satwa liar harus segera diwujudkan.

Untuk menerapkan hukuman maksimal bagi pelaku kejahatan terhadap satwa liar, jaksa penuntut umum memegang peranan dalam menentukan putusan yang akan dijatuhkan hakim di pengadilan. Sebagai pedoman bagi para jaksa telah dikeluarkan Peraturan Jaksa Nomor 028 Tahun 2014 tentang Pedoman Penanganan Perkara Pidana Dengan Subyek Hukum Korporasi. Berdasarkan Peraturan Jaksa tersebut, tuntutan pidana diajukan kepada korporasi, pengurus korporasi, korporasi dan pengurus korporasi. Dalam hal undang-undang tidak mengatur subyek hukum korporasi, maka tuntutan diajukan kepada pengurus. Sementara itu sebagai pedoman bagi para hakim dalam memeriksa kasus yang melibatkan korporasi, telah dikeluarkan Peraturan Mahkamah Agung Nomor 13 Tahun 2016 tentang Tata Cara Penanganan Perkara Tindak Pidana Oleh Korporasi. Namun dalam kenyatannya penegakan hukum konservasi belum banyak menjerat pelaku kejahatan satwa liar sebagai kejahatan yang terorganisasi, dan belum berhasil menjerat korporasi khususnya yang konsesinya sebagai habitat satwa liar dilindungi.

\section{Pengaturan Pertanggungjawaban Pidana Korporasi Dikaitkan Dengan Kejahatan Terhadap Satwa Liar \\ Undang-Undang Nomor 32 Tahun 2009 tentang Perlindungan dan Pengelolaan Lingkungan}


Hidup (UUPPLH) mengakui korporasi sebagai subyek hukum pidana yang dapat berbuat dan bertanggung jawab pidana. Pengakuan ini dimulai dari pengaturan dalam Pasal 1 angka 32, yang menyatakan bahwa setiap orang adalah orang perseorangan atau badan usaha, baik yang berbadan hukum maupun tidak berbadan hukum..$^{20}$ Sementara itu sistem pertanggungjawaban pidana korporasi diatur dalam Pasal 116 sampai dengan Pasal 119 UUPPLH.

Salah satu isu penting dalam pertanggungjawaban pidana korporasi adalah menentukan pihak yang dapat dimintakan pertanggungjawaban. Menurut Nico Keijzer sebagaimana dikutip oleh Raynaldo Sembiring, pertanggungjawaban pidana korporasi memiliki beberapa teori yang dikenal di beberapa Negara, yaitu: ${ }^{21}$

a. Teori Identifikasi (Inggris)

Pertanggungjawaban pidana korporasi berdasarkan tindakan organ tertentu (Direksi) dalam korporasi.

b. Teori Aggregasi (Amerika Serikat) Pertanggungjawaban pidana korporasi berdasarkan tindakan satu atau lebih pegawainya yang memenuhi unsur delik.

c. Teori Budaya Korporasi

Pertanggungjawaban pidana korporasi berdasarkan keadaan dimana pelanggaran sesuai dengan budaya di dalam korporasi tersebut.

d. Vicarious Liability

Korporasi bertanggung jawab atas tindakan orang di dalamnya.

\section{e. Strict Liability}

Pertanggungjawaban korporasi secara mutlak.

Salah satu upaya penting untuk meminimalisasi kejahatan terhadap satwa liar adalah melalui penegakan hukum pidana. Dalam UUKH telah diatur tentang ketentuan pidana ini, yaitu dalam Pasal 40, yang dikaitkan dengan kejahatan dan pelanggaran Pasal 19, Pasal 21, dan Pasal 33 UUKH. Dari ketiga pasal tersebut, ketentuan yang merupakan kejahatan terhadap satwa liar adalah Pasal 21 ayat (2) yang menyatakan bahwa setiap orang dilarang untuk:

a. Menangkap, melukai, membunuh, menyimpan, memiliki, memelihara, mengangkut, dan memperniagakan satwa yang dilindungi, dalam keadaan hidup.

b. Menyimpan, memiliki, memelihara, mengangkut, dan memperniagakan satwa yang dilindungi dalam keadaan mati.

c. Mengeluarkan satwa yang dilindungi dari suatu tempat di Indonesia ke tempat lain di dalam atau di luar Indonesia.

d. Memperniagakan, menyimpan, atau memiliki kulit, tubuh, atau bagianbagian lain satwa yang dilindungi atau barang-barang yang dibuat dari bagian-bagian satwa tersebut atau mengeluarkannya dari suatu tempat di Indonesia ke tempat lain di dalam atau di luar Indonesia.

e. Mengambil, merusak, memusnahkan, memperniagakan, menyimpan, atau memiliki telur dan/atau sarang satwa yang dilindungi.

Sementara itu yang termasuk dalam pelanggaran adalah semua ketentuan dalam pasal-pasal tersebut yang dilakukan karena kelalaian pelaku serta ketentuan dalam Pasal 33 ayat (1) UUKH, yang menyatakan bahwa setiap orang dilarang melakukan kegiatan yang dapat mengakibatkan perubahan terhadap keutuhan zona inti taman nasional.

UUKH belum mengakomodasi kejahatan yang dilakukan oleh korporasi. Pada dasarnya tujuan pemidanaan korporasi terkait dengan tujuan pemidanaan yang bersifat integratif, yaitu: ${ }^{22}$

\footnotetext{
20 Maradona, "Penegakan Hukum Lingkungan: Administrasi dan Pidana", dalam Laode M. Syarif dan Andri G. Wibisana, tanpa tahun, Hukum LIngkungan: Teori, Legislasi, dan Studi Kasus, USAID, Kemitraan, The Asia Foundation, hlm. 531

1 Raynaldo Sembiring, et.al, Op. cit., hlm. 269

22 Eddy O.S. Hiariej, 2016, Prinsip-prinsip Hukum Pidana (Edisi Revisi), Cahaya Atma Pustaka, Yogyakarta, hlm. 206.
} 
a. Tujuan pemidanaan untuk pencegahan, baik secara umum maupun khusus, yaitu pidana dianggap mempunyai daya untuk mendidik dan memperbaiki serta mencegah orang lain untuk melakukan suatu tindak pidana.

b. Tujuan pemidanaan untuk perlindungan masyarakat, secara luas yaitu tujuan fundamental sebagai tujuan dari semua pemidanaan, dan secara sempit adalah sebagai bahan pengadilan melalui putusannya agar masyarakat terlindung dari pengulangan tindak pidana.

c. Tujuan pidana untuk melahirkan solidaritas masyarakat yaitu untuk mencegah adat istiadat masyarakat dan mencegah balas dendam perseorangan atau balas dendam tidak resmi.

d. Tujuan pemidanaan untuk pengimbangan atau pengimbalan yaitu adanya kesebandingan antara pidana dengan pertanggungjawaban individual dari pelaku tindak pidana.

Awal tahun 2015 semula diharapkan menjadi titik cerah semangat perubahan UUKH, namun revisi tersebut secara resmi dihentikan oleh Pemerintah. ${ }^{23}$ Dewan Perwakilan Rakyat (selanjutnya disebut DPR) menganggap bahwa Rancangan UndangUndang Konservasi Sumber Daya Alam Hayati dan Ekosistemnya (selanjutnya disebut RUU KSDAE) belum perlu diundangkan karena UUKH dianggap masih relevan dengan permasalahan sumber daya alam hayati saat ini.

Berdasarkan perkembangan kejahatan saat ini, di mana korporasi merupakan salah satu pihak yang berkontribusi terhadap kerusakan lingkungan, pencemaran lingkungan, dan ketidakseimbangan flora dan fauna di alam, menurut Penulis UUKH sudah tidak relevan dengan keadaan di Indonesia saat ini. UUKH tidak mengatur pertanggungjawaban pidana korporasi, meskipun dalam revisi UUKH ada pasal yang mengatur pertanggungjawaban pidana korporasi, namun Pemerintah menghentikan upaya revisi tersebut. Pasal 200 RUU KKHE menentukan bahwa dalam hal tindak pidana konservasi keanekaragaman hayati dan ekosistem dilakukan oleh atau atas nama suatu korporasi, tuntutan dan penjatuhan pidana dilakukan terhadap pengurusnya. Pasal 201 RUU KKHE menyatakan bahwa:

a. Dalam hal korporasi dijatuhi pidana, maka korporasi tersebut diwakili oleh pengurus

b. Hakim dapat memerintahkan supaya pengurus korporasi menghadap sendiri di sidang pengadilan atau memerintahkan supaya pengurus tersebut dibawa ke sidang pengadilan

c. Pidana pokok yang dapat dijatuhkan terhadap korporasi hanya pidana denda dengan ketentuan maksimum pidana ditambah sepertiga untuk masing-masing pidana yang diatur dalam Undang-Undang ini.

Pasal 202 RUU KKHE menyatakan bahwa, selain dapat dijatuhi pidana denda, korporasi dapat dijatuhi pidana tambahan berupa penutupan seluruh atau sebagian perusahaan atau pencabutan izin. Adapun ancaman pidana denda dalam RUU tersebut paling banyak adalah 10 miliar rupiah. Dengan tidak diaturnya pertanggungjawaban pidana korporasi dalam UUKH, serta dihentikannya revisi UUKH, dalam hal terjadi kejahatan terhadap satwa liar, peraturan hukum yang digunakan adalah UndangUndang Nomor 8 Tahun 2010 tentang Pencegahan dan Pemberantasan Tindak Pidana Pencucian Uang.

Pendekatan tindak pidana pencucian uang sudah menjadi rekomendasi internasional dalam menjerat pelaku perdagangan satwa liar illegal. Saat ini perdagangan illegal satwa liar menduduki posisi nomor 5 sebagai kejahatan di dunia setelah narkotika, pemalsuan, perdagangana manusia, dan penyelundupan minyak. Undang-undang tindak pidana pencucian uang dapat menjerat pelaku dengan hukuman penjara maksimal 20 tahun dan

23 Dewi Purningsih, “Gagal Rampung, Revisi UU Konservasi Belum Menjadi Prioritas”, https://www.greeners.co/berita/gagal-rampung-revisiUU-konservasi-belum-menjadi-prioritas/ 
denda paling banyak 20 miliar rupiah. Selain itu, dana dan aset kejahatan dapat dibekukan dan dikembalikan ke negara. ${ }^{24}$ Meskipun Pemerintah telah menerapkan beberapa peraturan untuk menjerat pelaku, namun peraturan tersebut tidak secara spesifik menyasar pada perlindungan satwa liar. Terkait dengan pengaturan pertanggungjawaban korporasi terhadap kejahatan satwa liar, ada tiga hal yang penting dalam pengaturan itu, yaitu siapa yang disebut sebagai korporasi, siapa yang dapat dijatuhi pidana, dan sanksi apa yang seharusnya dijatuhkan kepada korporasi tersebut. Berikut perbandingan beberapa Undang-undang yang digunakan untuk menjerat pelaku kejahatan satwa liar yang dilakukan oleh korporasi:

Undang-Undang Nomor 32 Tahun 2009 tentang Perlindungan dan Pengelolaan Lingkungan Hidup: a) Siapa korporasi: badan usaha, baik berbadan hukum maupun tidak berbadan hukum; b) Siapa yang dipidana: badan usaha, pemberi perintah, dan/atau pemimpin kegiatan; c) Sanksi yang dijatuhkan: pidana pokok (penjara, diperberat sepertiga, dan denda diperberat sepertiga), pidana tambahan (perampasan keuntungan yang diperoleh dari tindak pidana, penutupan seluruh atau sebagian tempat usaha dan/atau kegiatan, perbaikan akibat tindak pidana, pewajiban mengerjakan apa yang dilalaikan tanpa hak, penempatan perusahaan di bawah pengampuan paling lama 3 (tiga) tahun).

Undang-Undang Nomor 8 Tahun 2010 tentang Pencegahan dan Pemberantasan Tindak Pidana Pencucian Uang: a) Siapa korporasi: kumpulan orang dan/atau kekayaan yang terorganisasi, baik merupakan badan hukum maupun bukan badan hukum; b) Siapa yang dipidana: korporasi dan/ atau personil pengendali korporasi; c) Sanksi yang dijatuhkan: pidana pokok (denda maksimal 100 miliar rupiah), pidana tambahan (pengumuman putusan hakim, pembekuan sebagian atau seluruh kegiatan usaha korporasi, pencabutan izin usaha, pembubaran dan/atau pelarangan korporasi, perampasan asset korporasi untuk negara, dan/atau pengambilalihan korporasi oleh negara).

Undang-Undang Nomor 17 Tahun 2006 tentang Perubahan atas Undang-Undang Nomor 10 Tahun 1995 tentang Kepabeanan: a) Siapa korporasi: badan hukum, perseroan atau perusahaan, perkumpulan, yayasan atau koperasi; b) Siapa yang dipidana: badan hukum, perseroan atau perusahaan, perkumpulan, yayasan atau koperasi; dan mereka yang memberikan perintah untuk melakukan tindak pidana tersebut atau yang bertindak sebagai pimpinan atau yang melalaikan pencegahannya; c) Sanksi yang dijatuhkan: pidana pokok (denda maksimal 1 miliar 500 juta rupiah, pidana penjara).

Undang-Undang Nomor 21 Tahun 2019 tentang Karantina Hewan, Ikan dan Tumbuhan: a) Siapa korporasi: badan hukum dan tidak berbadan hukum; b) Siapa yang dipidana: Dalam Pasal 86 tentang Ketentuan Pidana tidak mengatur pertanggungjawaban pidana korporasi. UU ini fokus pada sistem pencegahan masuk, keluar, dan tersebarnya hama dan penyakit hewan karantina serta pengawasan dan/atau pengendalian keamanan pangan dan mutu pangan, keamanan pakan dan mutu pakan, produk rekayasa genetik, sumber daya genetik, dan sebagainya.

Sementara itu ketentuan umum tentang korporasi diatur dalam Buku I Pasal 52 sampai dengan Pasal 57 RUU KUHP. Tindak pidana korporasi menurut Pasal 53 adalah Tindak Pidana yang dilakukan oleh orang yang mempunyai kedudukan fungsional dalam struktur organisasi Korporasi yang bertindak untuk dan atas nama Korporasi atau bertindak demi kepentingan Korporasi, yang berdasarkan hubungan kerja atau berdasarkan hubungan lain dalam lingkup usaha atau kegiatan Korporasi tersebut, baik secara sendiri-sendiri maupun secara bersama-sama. Selanjutnya Pasal 54 menentukan bahwa:

“(1) Selain sebagaimana dimaksud dalam Pasal 53, Tindak Pidana oleh Korporasi

24 Chik Rini, "Pelaku Kejahatan satwa Liar Dilindungi Bakal Dijerat Undang-Undang Pencucian Uang”, https://www.mongabay.co.id/2017/02/05/ pelaku-kejahatan-satwa-liar-dilindungi-bakal-dijerat-undang-undang-pencucian-uang/, diakses 22 Agustus 2019 
dapat dilakukan oleh pemberi perintah atau pemegang kendali Korporasi yang berada di luar struktur organisasi, tetapi dapat mengendalikan Korporasi.

(2) Pemberi perintah atau pemegang kendali Korporasi yang berada di luar struktur organisasi sebagaimana dimaksud pada ayat (1) dilakukan jika:

a. menguntungkan Korporasi secara melawan hukum; dan

b. bersifat langsung berkaitan dengan lingkup usaha atau kegiatan Korporasi dan diterima sebagai kebijakan Korporasi."

Berdasarkan pengaturan pertanggungjawaban pidana korporasi tersebut, ada beberapa hal penting, antara lain: ${ }^{25}$

a. Dalam hal ruang lingkup siapa yang disebut dengan korporasi, terdapat dua bentuk pengaturan, yaitu regulasi yang mensyaratkan bahwa korporasi harus berbentuk badan hukum, dan regulasi yang juga menjangkau korporasi berbentuk non-badan hukum. Dalam PERMA No. 13/2016 dan PERJA No. PER-028/A/ JA/10/2014 sendiri, Mahkamah Agung dan Kejaksaan Agung tidak membatasi korporasi harus berbadan hukum. Hal ini sepertinya untuk mengakomodasi variasi dari berbagai aturan undangundang. Dalam kejahatan konservasi sendiri, terdapat kasus-kasus dimana pelakunya adalah korporasi dalam bentuk non-badan hukum, seperti Persekutuan Komanditer (CV) yang bergerak di bidang penangkaran satwa.

b. Ketika terjadi tindak pidana, siapa saja yang dapat dijerat. Hendaknya tindak pidana korporasi tidak hanya menjerat pelaku fisik, tetapi juga badan usaha serta pelaku fungsionalnya. Siapa yang dapat dikategorikan sebagai pelaku fungsional merupakan perdebatan panjang, tidak semua pengurus korporasi dapat dikatakan sebagai pelaku fungsional. Kesalahan yang terjadi dalam beberapa kasus tindak pidana korporasi adalah penegak hukum menjerat pengurus yang tidak tahu apa-apa atau yang hanya sekedar mewakili korporasi di pengadilan sebagai pelaku fungsional yang dijatuhi hukuman. Pelaku fungsional haruslah orang yang memiliki power dan control ketika tindak pidana tersebut terjadi.

c. Sanksi yang dijatuhkan pada tindak pidana korporasi, terutama jika yang dijerat adalah badan usahanya, tentu tidak bisa menggunakan sanksi pidana konvensional yang hanya berupa penjara dan denda saja. Badan usaha tidak dapat dikenakan penjara. Sanksi yang cocok untuk badan usaha adalah berupa denda, perampasan hak dan tindakan paksaan tertentu. Bentuk badan usaha, apakah berbentuk badan hukum atau non-badan hukum juga akan mempengaruhi sanksi yang dapat dijatuhkan.

Penjatuhan sanksi pada korporasi seharusnya tidak hanya bersifat menghukum, tetapi harus diarahkan untuk perbaikan atau pemulihan ekosistem yang telah terganggu akibat perbuatannya, misalnya ketentuan pidana denda yang diperberat. Pidana denda ini seharusnya dapat digunakan untuk membayar kompensasi kepada Negara karena kejahatan yang dilakukan dapat merugikan keuangan negara, mengganti kerugian ekologis yang ditimbulkan dari kejahatan itu, misalnya biaya rehabilitasi satwa, penyediaan habitat untuk konservasi in situ atau ex situ, melakukan pemulihan lingkungan hidup, dan sebagainya. Dengan demikian, pidana denda ini dapat menimbulkan efek jera bagi korporasi. Selain 
itu, sejalan dengan UUPPLH, maka ancaman pidana penjara juga sebaiknya diatur ketentuan pidana penjara minimum dan maksimum.

Korporasi mempunyai peranan penting dalam upaya globalisasi melalui proses pembangunan di bidang ekonomi. Peranan korporasi dalam perkembangan aktivitasnya dapat meningkatkan pertumbuhan ekonomi melalui pemasukan negara dalam bentuk pajak atau devisa, serta penyediaan lapangan kerja yang luas bagi masyarakat. Namun kebijakan pemerintah yang berorientasi pada upaya meningkatkan pertumbuhan ekonomi dengan membangunberbagai industri yang operasionalnya banyak diperankan oleh korporasi, tidak jarang dalam aktivitasnya menunjukkan perilaku menyimpang. Penyimpangan perilaku korporasi dalam aktivitasnya inilah yang dikenal dengan istilah kejahatan korporasi. ${ }^{26}$

John Elkington sebagaimana dikutip oleh Muhammad Topan, menyusun 4 jenis korporasi berdasarkan daya rusaknya terhadap lingkungan hidup dengan menggunakan metafor serangga, yaitu: ${ }^{27}$

\section{a. Korporasi ulat (caterpillar)}

Ulat adalah serangga yang mampu melahap dedaunan dalam waktu sekejap dan hanya menyisakan rangka dan sirip. Dalam sistem ekonomi yang didominasi oleh korporasi ulat, sumber daya alam akan dilahap sedemikian rupa untuk kepentingannya sendiri di atas pengorbanan sustainabilitas lingkungan hidup dan kehidupan sosial ekonomi setempat. Korporasi ulat disamakan dengan perusahaan yang mendapat peringkat

\section{hitam.}

\section{b. Korporasi belalang (locust)}

Perusahaan berperingkat merah, cocok dimasukkan dalam jenis ini. Mereka mengeksploitasi sumber daya alam melampaui daya dukung ekologi, sosial, dan ekonomi. Dampaknya sangat degeneratif, regional, dan internasional. Korporasi ini menganggap CSR (Corporate Social Responsibility) sebagai cost, sehingga mereka baru menyelenggarakan CSR ketika ada tekanan dari masyarakat.

\section{c. Korporasi kupu-kupu (butterfy)}

Perusahaan ini memiliki kepedulian terhadap lingkungan hidup dan sosial. Perusahaan berperingkat hijau masuk dalam jenis ini.

\section{d. Korporasi lebah madu (honeybee)}

Berbeda dari korporasi belalang yang degeneratif, korporasi jenis ini justru bersifat regeneratif. Dalam versi proper perusahaan jenis ini berperingkat emas.

Berdasarkan uraian di atas, maka sudah menjadi urgensitas untuk mengatur pertanggungjawaban pidana korporasi dalam UUKH demi kelestarian satwa liar yang merupakan bagian dari keanekaragaman hayati di Indonesia. Pertanggungjawaban terhadap badan usaha bertujuan untuk mengejar perbaikan dampak dan mencegah badan usaha digunakan kembali untuk melakukan tindak pidana. Ketika akan menjerat pengurus sebagai pelaku fungsional haruslah memenuhi kriteria bahwa pengurus tersebut mempunyai kendali (power and control) terhadap tindak pidana ketika tindak pidana tersebut terjadi. Pengurus yang hanya sebatas mewakili korporasi di pengadilan dan/atau pengurus yang tidak punya kendali apa-apa ketika tindak pidana tersebut terjadi tidak dapat dijerat sebagai pelaku fungsional. ${ }^{28}$

\section{Kesimpulan}

Pertanggungjawaban pidana korporasi terhadap kejahatan satwa liar penting untuk diatur, karena korporasi mempunyai peranan penting terhadap perekonomian nasional, misalnya meningkatkan penerimaan negara melalui pajak,

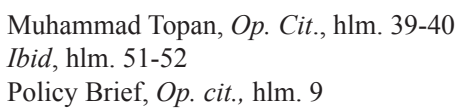


menciptakan lapangan kerja, alih teknologi, dan sebagainya; korporasi ingin memanfaatkan sumber daya alam semaksimal mungkin; Kejahatan di bidang satwa liar bernilai ekonomi tinggi; kejahatan satwa liar banyak melibatkan korporasi sebagai wadah perbuatannya, sehingga korporasi merupakan salah satu pihak yang berkontribusi terhadap ketidakseimbangan ekosistem; pentingnya penguatan hukum dalam perlindungan satwa liar di Indonesia.

Pengaturan pertanggungjawaban pidana korporasi terhadap kejahatan satwa liar: pertanggungjawaban pidana korporasi tidak diatur dalam UUKH, namun dalam RUU KKHE (Rancangan Undang-Undang Konservasi Keanekaragaman
Hayati dan Ekosistemnya) diatur dalam Pasal 200202. Solusi untuk menjerat pelaku kejahatan satwa liar oleh korporasi dengan menggunakan berbagai UU, yang tujuannya untuk mengoptimalkan jangkauan hukum terhadap pelaku dengan menggunakan kombinasi dari berbagai regulasi.

Berdasarkan kesimpulan tersebut, maka dapat diberikan saran bahwa sudah saatnya Pemerintah mengatur pertanggungjawaban pidana korporasi terhadap kejahatan satwa liar, agar kelestarian satwa tersebut tetap terjaga. Pemerintah dan korporasi harus lebih memandang sumber daya alam sebagai satu kesatuan yang utuh dengan keberadaan satwa dan masyarakat lokal di dalamnya, agar tujuan konservasi satwa liar dapat tercapai.

\section{DAFTAR PUSTAKA}

\section{A. Buku}

Alikodra, Hadi. S, 2012, Konservasi Sumber Daya Alam dan Lingkungan: Pendekatan Ecosophy bagi Penyelamatan Bumi, Gadjah Mada University Press, Yogyakarta.

Fajar, Mukti, dan Yulianto Achmad, 2010, Dualisme Penelitian Hukum Normatif dan Empiris, Pustaka Pelajar, Yogyakarta.

Hiariej, Eddy O.S., 2016, Prinsip-prinsip Hukum Pidana (Edisi Revisi), Cahaya Atma Pustaka, Yogyakarta.

Kelompok Kerja Konservasi, 2018, Catatan Akhir tahun 2018 Kelompok Kerja Konservasi: nasib gantung Konservasi Keanekaragaman Hayati, Kerjasama ICEL, FKKM, KEHATI, PILI, WWF, WCS.

Maradona, "Penegakan Hukum Lingkungan: Administrasi dan Pidana”, dalam Laode M. Syarif dan Andri G. Wibisana, tanpa tahun, Hukum LIngkungan: Teori, Legislasi, dan Studi Kasus, USAID, Kemitraan, The Asia Foundation.

Santosa, Mas Achmad, 2016, Alam pun Butuh Hukum dan Keadilan, Cetakan I, as@-prima pustaka, Jakarta.
Sembiring, Raynaldo, dan Wenni Adzkia, 2014, Anotasi Undang-Undang Nomor 32 Tahun 2009 Tentang Perlindungan dan Pengelolaan LIngkungan Hidup Edisi I, ICEL, Jakarta.

Soekanto, Soerjono, 1986, Pengantar Penelitian Hukum, UI Press, Jakarta.

Supriatna, Jatna, 2008, Melestarikan Alam Indonesia, Edisi pertama, Yayasan Obor Indonesia, Yogyakarta.

Topan, Muhammad, 2009, Kejahatan Korporasi di Bidang Lingkungan Hidup: Perspektif Viktimologi Dalam Pembaharuan Hukum Pidana di Indonesia, Cetakan I, Nusa Media, Bandung.

\section{B. Jurnal}

Policy Brief 6, "Proyeksi Penerapan Pertanggungjawaban Korporasi Dalam Kejahatan Konservasi”, ICEL, Jakarta, 2019.

Sembiring, Raynaldo, dan Wenni Adzkia, "Memberantas Kejahatan atas Satwa Liar: Refleksi Atas Penegakan Hukum UU No. 5 Tahun 1990”, Jurnal Hukum Lingkungan, Vol. 2, Issue 2, Desember 2015. 


\section{Internet}

Arinta, Nur, "PPATK: Mari Bersama Stop Perdagangan Ilegal Satwa Liar Dilindungi Hingga ke Akarnya", wwf.id/publikasil ppatk-mari-bersama-stop-perdaganganilegal-satwa-liar-dilindungi-hingga-keakarnya, diakses Tanggal 6 September 2020.

Kementerian Keuangan, "20 Ton Sirip Hiu Gagal ke Hong Kong", https://www.kemenkeu.go.id// publikasi/berita/20-ton-sirip-hiu-gagal-kehong-kong/, diakses Tanggal 17 Maret 2019.

Kementerian Luar Negeri RI, "Kejahatan Lintas Negara", https://www.kemlu.go.id, diakses Tanggal 10 Maret 2019.

Maharani, Tsarina, "Menteri Lingkungan Hidup dan Kehutanan: Kejahatan satwa Liar Peringkat ke-3 di Indonesia", https://m. detik.com., 1 Mei 2018, diakses Tanggal 10 Maret 2019.

Purningsih, Dewi, "Gagal Rampung, Revisi UU Konservasi Belum Menjadi Prioritas", https://www.greeners.co/berita/gagalrampung-revisi-UU-konservasi-belummenjadi-prioritas/, diakses Tanggal 5 September 2020.

Rini, Chik "Pelaku Kejahatan satwa Liar Dilindungi Bakal Dijerat Undang-Undang Pencucian Uang", https://www.mongabay. co.id/2017/02/05/pelaku-kejahatan-satwa- liar-dilindungi-bakal-dijerat-undangundang-pencucian-uang/, diakses Tanggal 22 Agustus 2019.

WWF, "Spesies", https://www.wwf.or.id, diakses Tanggal 8 Maret 2019.

\section{Peraturan Perundang-undangan}

Undang-undang Nomor 5 Tahun 1990 tentang Konservasi Sumber Daya Alam Hayati dan Ekosistemnya (Lembaran Negara Reprublik Indonesia Tahun 1990 Nomor 49).

Undang-undang Nomor 17 Tahun 2006 tentang Perubahan Atas Undang-undang No. 10 Tahun 1995 tentang Kepabeanan (Lembar Negara Reprublik Indonesia Tahun 2006 Nomor 93).

Undang-undang Nomor 32 Tahun 2009 tentang Perlindungan dan Pengelolaan Lingkungan Hidup (Lembar Negara Reprublik Indonesia Tahun 2009 Nomor 140).

Undang-undang Nomor 8 Tahun 2010 tentang Pencegahan dan Pemberantasan Tindak Pidana Pencucian Uang (Lembar Negara Reprublik Indonesia Tahun 2010 Nomor 122).

Undang-undang Nomor 21 Tahun 2019 tentang Karantina Hewan, Ikan dan Tumbuhan (Lembar Negara Reprublik Indonesia Tahun 2009 Nomor 20). 